\title{
Bio-chemical characterization of bacterial flora associated with spoilt vegetables in Kaduna markets Northern Nigeria
}

\author{
F. M. Mahamud ${ }^{1 *}$, D. B. Dangora ${ }^{2}$, S. Mu'azu' ${ }^{2}$ A. U. Khan ${ }^{2}$, S. Nura ${ }^{3}$, Z. A. Gaiya ${ }^{4}$ \\ ${ }^{1}$ Department of Applied Science, Kaduna Polytechnic, Kaduna, Nigeria \\ ${ }^{2}$ Department of Biological Sciences, Ahmadu Bello University, Zaria, Nigeria \\ ${ }^{3}$ School of Basic and Remedial Studies, Ahmadu Bello University, Funtua, Nigeria \\ ${ }^{4}$ Department of Microbiology, Ahmadu Bello University, Zaria, Nigeria \\ Email: "barmass4real@yahoo.com
}

Received 14 November 2012; revised 16 December 2012; accepted 27 December 2012

\begin{abstract}
Some vegetables such as Capsicum annum (Pepper), Lycopersicon esculentum (Tomato), Allium cepa (Onion), Cucumis sativus (Cucumber), Solanum tuberosum (Potato) and Daucus carrota (Carrot) which are consumed more frequently in the area were obtained from Kaduna central market and Kawo market with the aim of isolating and characterizing the different bacterial flora associated with their spoilage. Four bacteriological media: Mannitol Salt Agar (MSA), MacConkey Agar (MA), Salmonella Shigella Agar (SSA) and Blood Agar (BA) were used for the isolation of the bacterial populations. The results obtained from Kaduna central market indicated the presence of two Gram positive bacteria viz: Staphylococcus and Streptococcus strains as well as three Gram negative bacteria including Escherichia coli, Citrobacter and Klebsiella spp. Staphylococcus aureus is the most abundant (with $80 \%$ relative occurrence) with Streptococcus spp being the least abundant (with $10 \%$ relative occurrence). Furthermore, among the Gram negative isolates, Escherichia coli, Citrobacter and Klebsiella spp had the highest occurrence of $30 \%$ each, while Enterobacter spp had the least. Similar results were obtained of the isolates from Kawo market except that among the Gram negatives, Edwardsiella spp was found in Kawo market but $E$. coli is absent. More so, $S$. aureus and $K$. spp has the highest percentage of 605 each in Kawo market. The result showed that the people consuming these vegetables are at higher risk of boils, carbuncles, impetigo, infections of wounds and burns, breast abscesses, whitlow, osteomyelitis, bronchopneumonia, septicemia, bacteremia, acute endocarditis, food poisoning and scalded skin syndrome due to these bacterial populations.
\end{abstract}

"Corresponding author.
Keywords: Bacterial Flora; Characterization; Kawo Market; Kaduna Market; Vegetables

\section{INTRODUCTION}

Vegetables are the edible product of an herbaceous plant that are mostly valuable sources of vitamins, minerals and fiber and are low in fat and calories [1,2]. Vegetables are vital sources of nutrient to human beings. They give the body the necessary vitamins, fats, minerals and oil in the right proportion for human growth and development [3]. The nutritional content of vegetables varies considerably, though generally they contain little protein or fat $[4,5]$ and varying proportions of vitamins, provitamins, dietary minerals, fiber and carbohydrates. Vegetables contain a great variety of other phytochemicals, some of which have been claimed to have antioxidant, antibacterial, antifungal, antiviral and anticarcinogenic properties [6]. This quality makes the vegetables to be suitable environment for bacterial and other microbial growth and development.

The occurrence of bacterial populations on vegetables is recognized as a source of potential health hazard to man and his animals. This is due to their production of bacteriotoxins compounds which are capable of inducing several critical clinical symptoms in man following ingestion or inhalation; even though they differ in their degree and manner of toxicity. The contamination of fruits and vegetables by bacteria could also be as a result of poor handling practices in food supply chain, storage conditions, distribution, marketing practices and transportation [7]. Several varieties of vegetables were sold in Kaduna central market and Kawo market within Kaduna metropolis, Northern Nigeria. These vegetables includes roots such as carrot, a tuber or storage stem such as potato and sweet potato, a leaf such as cabbage, lettuce and spinach and immature flower such as watermelon and 
pumpkin as well as some fruits that are used as vegetables such as cowpea, cucumber, garden egg, okra, pepper, tomato, and bulbs such as onion. The sources of these vegetables are the irrigated farms within Kaduna metropolis and the neighboring states like Kano state and Niger state. They are transported to these markets in Lorries and buses packed in sacks and baskets. Human activities contribute greatly to post harvest contamination either through mishandling such as improper harvest handling or lack of proper storage measures and personal hygiene as those adopted in the two markets under study. The subsequent effect of which is the production of high microbial load, being passed on to the final consumer with the imminent risk of infection and illness. In order to find solution to this problem awareness has to be made of the health hazard this negligence poses to the larger society. This study therefore aimed at investigating the prevalence and occurrence of different bacterial species on the vegetables sold in Kaduna central market and Kawo market from Kaduna state, Northern Nigeria; with the view of identifying the different species of bacteria and their prevalence. The results of this research is also intended to be used in suggesting possible ways of minimizing or avoiding possible health problem associated with these bacterial species.

\section{MATERIALS AND METHOD}

The samples were collected from both the whole sellers and retailers in Kaduna Central market and Kawo market, Kaduna state, Nigeria (lat $10^{\circ} 31^{\prime \prime} 06.29^{\prime} \mathrm{N}$ and long $\left.7^{\circ} 25^{\prime \prime} 36.57^{\prime} \mathrm{E}\right)$. The vegetables used include: Pepper (Capsicum annum), Tomato (Lycopersicon esculentum), Carrot (Daucus carota), Cucumber (Cucumis sativus), Onion (Allium cepa), and Potato (Solanum tuberosum). The samples were collected twice monthly from the market, put into a clean polythene bag and labeled respectively. The samples were kept in the refrigerator at $4^{\circ} \mathrm{C}$ for later use.

\subsection{Bacterial Isolation from Deteriorated Vegetables}

For isolation of bacterial flora, the method of Dashwood, et al. [8] and Balali, et al. [9] was used. The surface of the vegetables that showed spoilage symptomatology were sterilized with $0.1 \%$ Mercury chloride $(\mathrm{HgCl})$ for 2 minutes then rinsed three times with distilled water. A sterile blade and forceps was use to cut small section of the tissue containing both the healthy and the rotten portion. The cut potions were pounded with pistil and mortar to make paste.

\subsection{Inoculation and Incubation}

Streaking method was used for inoculation of the organ- isms on the agar plates (MA, MSA, SSA and BA). The pulverized sample was transferred to the edge of an agar plates with a sterilized wire loop, and then a parallel, non-overlapping streaks were made on the surface of the already solidified agar plates and incubated in the incubator for 24 hours at $37^{\circ} \mathrm{C}$.

\subsection{Isolation and Characterization of Bacterial Colonies}

With the aid of a sterilized inoculating needle, a small portion of bacterial colony was transferred into the glass slide and teased properly with two sterilized inoculating needles as described by the method of Dashwood et al. [8]. The prepared slide was observed under low and high power resolution objectives of a compound microscope. Individual colonies were chosen and the top of an individual colony each was touch lightly with a sterile loop or needle and streak on a fresh agar plate The various colonies observed in the plates were distinguished on the basis of their cultural characteristics such as colony size, shape, color, consistency and haemolytic characteristics as described by Fawole and Oso [10]. Bacterial growth was sub-cultured on NA and was preserved in NA slants. The bacterial representative cultures distinguished on the basis of their cultural characteristics were smeared thinly on grease free microscopic slide. The smears were allowed to air dry and heat-fixed by passing the slide through the Bunsen flame. The heat-fixed smear was allowed to cool; and were Gram stained. The stained smears were then examined microscopically under the oil immersion lens. The organism recovered from the deteriorated vegetables were grouped on the basis of their Gram reaction, cell morphology and cell arrangement. The isolates were further characterized using biochemical test described by Faiers et al. [11] and Wreghitt and Morgan [12].

\subsection{Data Analysis}

The data collected was analyzed statistically using percentages with Chi $\left(\mathrm{X}^{2}\right)$ Square $(\mathrm{P}<0.05)$ to test whether there is association between symptoms and occurrence of the isolates.

\section{RESULTS}

The result of the biochemical characterization of Gram positive bacterial isolates on the vegetables in Central Market Kaduna was presented in Table 1. The result revealed the presence of Staphylococcus aureus and Streptococcus spp. as the Gram positive bacteria associated with the vegetables.

However, the result obtained in vegetables from Kawo market have shown that, $S$. aureus is the only Gram positive bacterial isolate (Table 2). 
Table 1. Biochemical characterization of gram positive bacterial isolates associated with spoilt vegetables in central market Kaduna.

\begin{tabular}{|c|c|c|c|c|c|c|c|c|}
\hline \multirow{2}{*}{ Vegetables } & \multirow{2}{*}{ Hem } & \multirow{2}{*}{ Coa } & \multicolumn{2}{|c|}{ Man } & \multirow{2}{*}{ Bil } & \multirow{2}{*}{ Cat } & \multirow{2}{*}{ DNA } & \multirow{2}{*}{ Inference } \\
\hline & & & O & $\mathbf{F}$ & & & & \\
\hline Tomato & $\mathrm{A}$ & + & + & - & - & + & + & S. aureus \\
\hline Cucumber & A & + & + & - & - & + & + & S.aureus \\
\hline Potato & A & + & + & - & - & + & + & S.aureus \\
\hline Onion & - & - & - & - & - & - & $+/-$ & Strepp spp \\
\hline Carrot & A & + & + & - & - & + & + & S.aureus \\
\hline Pepper & A & + & + & - & - & + & + & S.aureus \\
\hline
\end{tabular}

KEY: Hem = Haemolysis reaction; Coa = Coagulase reaction; DNA = Deoxyribo Nucleic Acid; Man = Mannitol fermentation; Bil = Bile solubility; Cat = Catalase; $+/-=$ Partial positive.

Table 2. Biochemical characterization of gram positive bacterial isolate associated with spoilt vegetables in Kawo market.

\begin{tabular}{|c|c|c|c|c|c|c|c|c|}
\hline \multirow{2}{*}{ Vegetable } & \multirow{2}{*}{ Hem } & \multirow{2}{*}{ Coa } & \multicolumn{2}{|c|}{ Man } & \multirow{2}{*}{ Bil } & \multirow{2}{*}{ Cat } & \multirow{2}{*}{ DNA } & \multirow{2}{*}{ Inference } \\
\hline & & & $\mathbf{O}$ & $\mathbf{F}$ & & & & \\
\hline Tomato & A & + & + & - & - & + & + & S. aureus \\
\hline Cucumber & A & + & + & - & - & + & + & S. aureus \\
\hline Potato & A & + & + & - & - & + & + & S. aureua \\
\hline Onion & A & + & + & - & - & + & + & S. aureus \\
\hline Carrot & A & + & + & - & - & + & + & S. aureus \\
\hline Pepper & A & + & + & - & - & + & + & S. aureus \\
\hline
\end{tabular}

Key: Hem: Haemolysis reaction; Coa: Coagulase reaction; DNA: DNASE; Man: Mannitol fermentation; Bil: Bile Solubility; Cat: Catalase; +/-: Partially positive.

More so, the results of the biochemical characterization of bacterial isolates from Central market were presented in Table 3. The results revealed the presence of four different Gram negative pathogens in form of Escherichia coli, Klebsiella spp., Enterobacter spp. and Citrobacter spp.

Further more in Kawo market, three bacterial isolates were found in form of Klebsiella spp., Edwardsiella spp. and Citrobacter spp. (Table 4).

Similarly, the result of the prevalence of different bacterial isolates on the spoilt vegetables of Central market is shown in Table 5. It showed that S. aureus is the most abundant bacterial flora with Strepp. spp. as the least. However, in Kawo market, S. aureus and Klebsiella spp. are the most abundant bacterial flora with Edwarsiella spp. and Citrobacter spp. as the least (Table 5).

\section{DISCUSSION}

Vegetables are dietary sources of nutrients to man and his animals. They increased the competition between man and other microbes leading to contamination through contact with soil, dust and water. Vegetables harbor a wide range of microbial contaminants [13]. Erin [14] reported that, the major bacterial species that are generally present on vegetables include species of Pseudomonas spp., Bacillus spp., Enterobacter spp., Sarcina spp.,
Staphylococcus spp., Streptococcus spp., Lactobacillus spp. and Leuconostoc spp. Most of the vegetables were not really fresh as they stayed in the market for long periods resulting to their spoilage [15]. More so, most of the vegetables were grown under irrigation water containing enteric bacteria, viruses, protozoa, or helminthes, which subsequently increases the probability of the isolation of pathogens from harvested produce as reported by Uzeh et al., [16]. The extent of spoilage depends on microorganisms involved. The prevalence of $S$. aureus in almost all the vegetables in the two markets have shown the degree at which such a microbe proliferate and compete successfully in respect of the other microbes. This finding is in conformity with that of Uzeh et al. [16] who reported the presence of $S$. aureus in carrots, cucumber, cabbage and lettuce at food outlets within Lagos Metropolis. The presence of Staphylococcus and Streptococcus species in the vegetables observed in this study also agrees with the work of Erin [14] who reported the presence of Staph spp. in pawpaw, orange and kola nut at Sango Market, Ilorin. However, this finding contradicts the work of Wells and Butterfield [17] who reported Salmonella, Shigella and gastro-intestinal viruses as the major pathogens associated with food poisoning in England and the United States.

The presence of other bacterial species of E. coli, Enterobacter spp., Citrobacter spp. and Klebsiella spp. in the 
Table 3. Biochemical characterization of gram negative bacterial isolates associated with spoilt vegetables in central market.

\begin{tabular}{ccccccccc}
\hline Vegetables & Ind & MR & VP & CIT & MOT & Urea & S/F & Inference \\
\hline Tomato & + & + & - & - & + & - & K/AG & E. coli \\
Cucumber & - & - & - & + & + & - & K/A & Klebsiella spp. \\
Potato & + & + & - & - & + & - & K/AG & E. coli \\
Onion & - & - & - & + & + & - & K/A & Klebsiella spp. \\
Carrot & - & - & + & + & + & - & K/A & Enterobacter spp. \\
Pepper & - & + & - & + & + & + & K/AGH & Citrobacter spp. \\
\hline
\end{tabular}

KEY: Ind = Indole; MR = Methyl Red; VP = Voges Proskae; Cit = Citrate test; Mot = Motility; Urea = Ureas; S/F = sugar fermentation.

Table 4. Biochemical characterization of gram negative bacterial isolates associated with spoilt vegetables in Kawo market.

\begin{tabular}{|c|c|c|c|c|c|c|c|c|}
\hline Vegetables & Ind & MR & $\mathrm{VP}$ & CIT & MOT & Urea & $\mathrm{S} / \mathrm{F}$ & Inference \\
\hline Tomato & - & - & - & + & + & - & $\mathrm{K} / \mathrm{A}$ & Klebsiella \\
\hline Cucumber & - & + & - & + & + & + & $\mathrm{K} / \mathrm{AGH}_{2} \mathrm{~S}$ & Citrobacter \\
\hline Potato & - & + & - & + & + & + & $\mathrm{K} / \mathrm{AGH}_{2} \mathrm{~S}$ & Citrobacter \\
\hline Onion & - & - & - & + & + & - & $\mathrm{K} / \mathrm{A}$ & Klebsiella \\
\hline Carrot & + & + & - & - & - & + & $\mathrm{K} / \mathrm{AGH}_{2} \mathrm{~S}$ & Edwardsiella \\
\hline Pepper & - & - & - & + & + & - & $\mathrm{K} / \mathrm{A}$ & Klebsiella \\
\hline
\end{tabular}

KEY: Ind = Indole; MR = Methyl Red; VP = Voges Proskaer; Cit $=$ Citrate test Mot = Motility; Urea $=$ Ureas; $\mathrm{S} / \mathrm{F}=$ sugar fermentat.

Table 5. Prevelance of bacterial isolates associated with spoilt vegetables in the two markets Kaduna.

\begin{tabular}{ccc}
\hline Bacterial Isolates & Percentages (\%) in Central market & Percentages (\%) in Kawo market \\
\hline S. aureus & 40 & 37.5 \\
Strep. spp. & 05 & - \\
E. coli & 15 & 37.5 \\
Klebsiella spp. & 15 & 12.5 \\
Edwardsiella spp. & - & - \\
Enterobacter spp. & 10 & 12.5 \\
Citrobacter spp. & 15 & 100 \\
Total & 100 & \\
\hline
\end{tabular}

vegetables obtained from Kaduna Central market and Kawo market conforms to the findings of Rangel et al. [18] in which they reported the presence of $E$. coli in lettuce, apple, salads, coleslaw, melons, sprouts and grapes. The presence of E. coli, Klebsiella, Citrobacter, Edwardsiella and Enterobacter may lead to diarrheal diseases. They are well known enteric pathogens of man in nosocomial infections. The majority of human infections are caused by Klebsiella pneumoniae and Klebsiella oxytoca [19].

The presence of Citrobacter spp. in the vegetables agrees with the findings of Uzeh et al. [16] who reported Citrobacter spp. in carrots, cucumber, cabbage and lettuce within Lagos Metropolis. Citrobacter spp is reported to be resistant to some antibiotics e.g. Penicillin. It was found to cause gastro-enteritis, acute gastroenteritis characterized by the symptoms of vomiting, nausea, fever, chills, abdominal pain, and watery (dehydrating) diarrhea occurring 12 - 24 hours after ingestion of contaminated food or water as reported by Anonymous [20]. Bacterial food poisoning have been implicated in the consumption of food contaminated by bacteria, most of the bacteria obtained from this study, were enteric bacteria which are found in the soil and air.

\section{CONCLUSION}

It was concluded that, the vegetables sold in the two markets harbor a great deal of microorganisms. These organisms have been known to produce toxins in vegetables they invade, thereby posing health hazard to their consumption. There is therefore the need for public awareness campaign through the media on the implications of consumption of vegetables contaminated by these organ- 
isms. Good handling and use of clean water for washing the vegetables ought to be advocated especially by the retailers.

\section{REFERENCES}

[1] Fasakin, K. (2004) Proximate composition of bungu (Ceratotheca sesamoides Endl.) leaves and seeds. Biokemistri, 16, 88-92.

[2] Anonymous (2009) Encarta encyclopedia. Microsoft Encarta Corporation Inc.

[3] Akinmusire, O.O. (2011) Fungal species associated with the spoilage of some edible fruits in Maiduguri NorthEastern Nigeria. Advances in Environmental Biology, 5, 157-161.

[4] Woodruff, S.L. (1995) Secrets of fat-free cooking: Over 150 fat-free and low-fat recipesfrom breakfast to dinner-appetizers to desserts. Avery Publishing Group, Garden City Park.

[5] Whitaker, J.M. (2001) Reversing diabetes. Warner Books, New York, 446.

[6] Gruda, N. (2005) Impact of environmental factors on product quality of greenhouse vegetables for fresh consumption. Critical Reviews in Plant Sciences, 24, 227247. doi:10.1080/07352680591008628

[7] Effiuvwevwere, B.J.O. (2000) Microbial spoilage agents of Tropical and assorted fruits and Vegetables (An Illustrated References Book). Paragraphics Publishing Company, Port Harcourt, 1-39.

[8] Dashwood, E.P., Fox, R.A. and Perry, D.A. (1992) Effects of inoculation source on roots and tubers infection by potato blemish disease fungi. Journal of Plant Pathology, 41, 215-223. doi:10.1111/j.1365-3059.1992.tb02340.x

[9] Balali, G.R., Neate, S.M., Scott, E.S., Idhisson, D.L. and Wicks, J.J. (1995) Anattomosis group pathogenicity of isolate of Rhizoctina solani from potato crops in South Australia. Journal of Plant Pathology, 44, 1050-1057. doi:10.1111/j.1365-3059.1995.tb02664.x

[10] Fawole, M.O. and Oso, B.A. (1995) Laboratory manual of microbiology. Spectrum Books Limited Ibadan, Owerri, 71-81.

[11] Faiers, M., George, R., Jolly, J. and Wheat, P. (1991) Multipoint methods. Clinical Laboratory, 3rd Edition, University Press Cambridge, Cambridge, 21-28.

[12] Wreghitt, T.G. and Morgan-Capner, P. (1990) ELISA in clinical microbiology laboratory. 3rd Edition, University Press Cambridge, Cambridge, 175-176

[13] Long, S.M., Adak, G.K., O’Brien, S.J. and Gillespie, I.A. (2002) General outbreak of infectious intestinal diseases linked with salad vegetables and fruits. England and Wales, 1992-2000. Communicable Disease and Public Health, 5, 101-105.

[14] Erin, S. (2010) Influence of pre-harvest factor on postharvest quality. Biochemistry, 2, 133-145.

[15] Sahin, F. and Miller, S.A. (1997) A source of resistance in Capsicum spp. Accession to pepper race 6 of Xanthomonas. Phytopathology, 87, 584.

[16] Uzeh, R.E., Alade, F.A. and Bankole, M. (2009) The microbial quality of pre-packed mixed vegetable salad in some retail outlets in Lagos Nigeria. African Journal of Food Science, 3, 270-272.

[17] Wells, J.M. and Butterfield, J.E. (1997) Salmonella contamination associated with bacterial soft rot of fresh fruits and vegetables in market places. Disease, 81, 867-872. doi:10.1094/PDIS.1997.81.8.867

[18] Rangel, J.M., Sparling, P.H., Crowe, C., Griffin, P.M. and Swerdlow, D.L. (2005) Epidemiology of Escherichia coli O157:H7 outbreaks, United States, 1982-2002. Emerging Infectious Diseases, 11, 603-609. doi:10.3201/eid1104.040739

[19] Pigott, D.C. (2008) Food borne illness. Emergency Medical Clinic North America, 26, 495-497. doi:10.1016/j.emc.2008.01.009

[20] Anonymous (2008) Food poisoning. www.foodinfo.net 